\title{
El arte urbano en las redes sociales como medio de transformación social: el caso de Boa Mistura
}

\author{
Carmen Haro Cáceres | Historiadora del arte \\ URL de la contribución <www.iaph.es/revistaph/index.php/revistaph/article/view/4905>
}

Desde sus inicios, el arte urbano ha tenido un componente puramente reivindicativo, un carácter vandálico que ha desencadenado en un fin social. La idea de reivindicar el propio espacio urbano y de que las calles fuesen lienzos en los que realizar arte estaba ya probablemente presente en la cabeza de Cornbread (Brewerytwon, Filadelfia, 1953) cuando empezó a inundar las calles de Filadelfia de los años sesenta con su apodo, iniciando una auténtica revolución artística con la creación del grafiti. De esta forma, el arte urbano comenzó a imponerse a otras manifestaciones artísticas cuya finalidad era económica, y consiguió alzarse como aquella capaz de transformar el espacio urbano.

Pero ¿por qué hablamos de una transformación? ¿Por qué esa necesidad de reivindicar el espacio urbano? La respuesta es que esta expresión artística que se desarrolla, sobre todo, en barrios humildes y excluidos socialmente, es capaz de revitalizar las calles, ponerles nombre a esos barrios olvidados, regenerarlos y darles una identidad colectiva con la que se reconozcan sus habitantes. La necesidad de reivindicar el espacio urbano, por tanto, se traduce en un trabajo social. En la labor de utilizar el arte como una herramienta para transformar el espacio público, y de crear vínculos y lazos sociales.

La realidad actual, sin embargo, es que el arte urbano no se ve solamente en las calles de nuestras ciudades, sino que cada vez es más habitual encontrarnos arte urbano en las redes sociales, convirtiéndose estas en lienzos digitales capaces de representar todo aquello que se está realizando a pie de calle. La mayoría de los y las artistas actuales están presentes en estas plataformas digitales, ya sea para exponer sus obras o con fines comerciales. Resulta, por tanto, interesante ver cómo quienes se dedican al arte urbano también llenan las redes sociales con aquellas obras realizadas en los muros de las calles, con el fin de enseñar qué se está haciendo en ese momento, o, también, de vender. El propio Cornbread, una leyenda para el arte urbano que hace poco se hizo ver en uno de los programas favoritos de este país, La Resistencia (Trincheras 2019), o Banksy, otra leyenda, se encuentran ya presentes en Instagram exponiendo todo lo que hacen.

También es el caso de Boa Mistura (@boamistura en Instagram), un equipo multidisciplinar con raíces en el grafiti que nació en el año 2001 en la ciudad de Madrid. En este equipo es en quien nos centraremos, explicando su caso y la labor que hacen en las calles y en las redes sociales. Su nombre viene del portugués, que significa "buena mezcla" y hace referencia a la infinidad de puntos de vista que existen en cada uno de nosotros. El trabajo de Boa Mistura se realiza, principalmente, en el espacio público, sintiendo su labor como una responsabilidad con la ciudad y el momento en el que viven. Han participado en una infinidad de proyectos "aquí y allá" (como ellos mismos señalan en su página web), recorriendo el

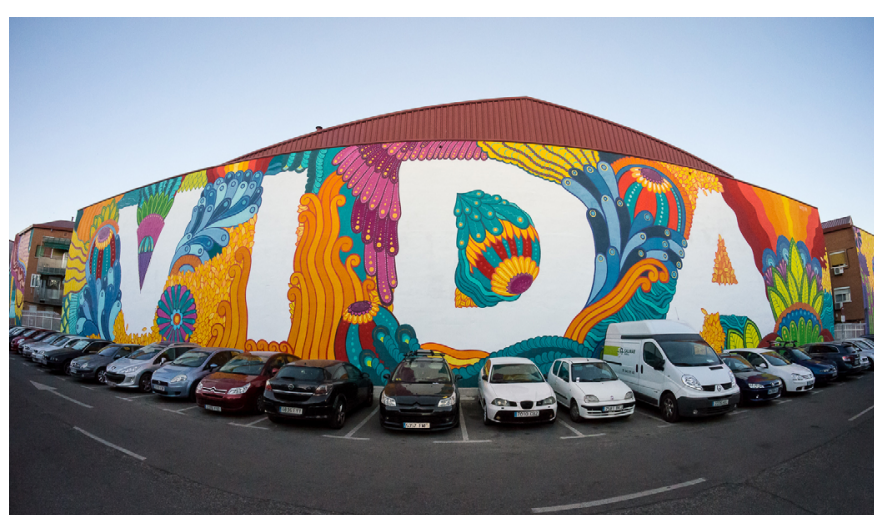

Boa Mistura. Getafe (Madrid) | foto r2hox 
mundo con el deseo de crear algo nuevo y transformador en los barrios que visitan. Las redes sociales son su espejo, su galería virtual a partir de la cual nosotros y nosotras, como público, podemos ver el trabajo que realizan. Pero no solo las utilizan como forma de exposición, sino como medio para vender.

Si investigáis sus perfiles en estas plataformas, veréis que todos sus proyectos los realizan en colaboración con la ciudadanía, que, al fin y al cabo, es la protagonista. En Instagram, a través de sus publicaciones, explican los proyectos y lo que les ha movido a realizarlos. Con los stories podemos ver su día a día recorriendo las carreteras, sus interacciones con los vecinos de un barrio $u$ otro, etc. Resulta realmente interesante la forma en la que se exponen en redes sociales porque nos permiten, así, conocer de primera mano todo el proceso artístico por el que van pasando los diferentes proyectos sociales que llevan a cabo. Un ejemplo es el de Te comería a versos, realizado en 2014 en las calles de Madrid y traducido como un acto de amor por poetas y músicos que transformó el asfalto en un poemario. Una canción cantada por el cantante español Leiva y titulada con el mismo nombre que el proyecto es la que anuncia lo que se está haciendo en las calles de Madrid (Cultura Inquieta 2014). A partir de un vídeo, subido a redes sociales y a su propia página web, Boa Mistura presenta su iniciativa de llenar los asfaltos con estrofas de poemas y canciones.

Otro ejemplo es El alma no tiene color, realizado en 2018 en La Cañada Real Galiana en Madrid. Este proyecto cuenta la historia de 18.000 personas que tratan de avanzar en un territorio estigmatizado por los medios. Dicho trabajo nace con el objetivo de dar voz a todas esas familias que viven excluidas de la sociedad, a la sombra de la propia Comunidad de Madrid.

El proyecto parte de una canción titulada con el mismo nombre, compuesta por Paqui Mayoral y Antonio Remache. A partir de ella, su letra es pintada por el vecindario en los muros de 61 viviendas de La Cañada Real. El objetivo es mostrar esa diversidad cultural que existe en nuestro país, teniendo como base al arte urbano como promotor de cambio social. Al igual que con Te comería a versos, El alma no tiene color se presenta a través de un vídeo documental subido a la página web y a algunas plataformas digitales como Vimeo (Arranz 2018).

Como estos dos ejemplos, Boa Mistura ha participado en muchos otros que ha ido presentando a través de sus redes sociales (Instagram, Facebook, Vimeo, etc.) y de su página web oficial. Pero, sin duda, lo importante de ellos es lo que representan: el cambio. La creencia de que el arte sí puede salvar vidas, y de que la participación ciudadana hace, en el arte, un bien al que acudir siempre que busquemos esa reconexión con la sociedad, y con la vida en general.

\section{BIBLIOGRAFÍA}

- Arranz, M. (2018) En la Cañada Real, "el alma no tiene color". El País, 14 de julio de 2018. Disponible en: https:// elpais.com/ccaa/2018/07/13/madrid/1531483526_562177. html [Consulta: 11/04/2021]

- García Gayo, E. y Luque Rodrigo, L. (2021) Dilemas del arte urbano como patrimonio. Revista $P H$, n. $^{\circ} 103$, pp. 106107. Disponible en: http://www.iaph.es/revistaph/index.php/ revistaph/article/view/4866 [Consulta: 11/04/2021]

- Cultura Inquieta (2014) Madrid, te comería a versos. Por Boa Mistura. Blog Cultura Inquieta, 22 de noviembre de 2014. Disponible en: https://culturainquieta.com/es/inspiring/ item/5148-madrid-te-comeria-a-versos.html [Consulta: 11/04/ 2021]

- Trincheras (2019) Mr. Cornbread, el bisabuelo grafitero. El Terrat, 29 de noviembre de 2019. Disponible en: https:// elterrat.com/mr-cornbread-el-bisabuelo-grafitero/ [Consulta: $11 / 04 / 2021]$ 